Article

\title{
Arboricultural Introductions and Long-Term Changes for Invasive Woody Plants in Remnant Urban Forests
}

\section{Robert E. Loeb}

Biology and Forestry, The Pennsylvania State University-DuBois Campus, One College Place, DuBois, PA 15801, USA; E-Mail: rx15@psu.edu; Tel.: +1-814-375-4739; Fax: +1-814-375-4784

Received: 2 July 2012; in revised form: 14 August 2012 / Accepted: 15 August 2012 /

Published: 27 August 2012

\begin{abstract}
Long-term changes for invasive trees and shrubs presence in 16 floras encompassing four remnant urban forests of the coastal northeastern United States were examined for relationships with arboricultural introductions' residence time and planting intensity, and state level recognition of regional invasive woody taxa. The number of invasive woody taxa significantly increased over the period 1818 to 2011 which encompasses the 16 floras. No significant Pearson product moment correlations were found for residence time as the year of introduction to arboriculture with presence in the 16 floras as well as with the 4 most recent floras. In contrast to residence time, planting intensity from the North American flora and two botanical gardens floras of the region from 1811 to 1818 and New York and Philadelphia parks floras from 1857 to 1903 did have significant correlations with the 16 floras and the 4 most recent floras. State level recognition of regional invasive woody taxa showed significant correlations with presence in all 16 floras as well as the 4 most recent floras. Monitoring for range expansion by the regional invasive woody taxa is essential because only $18 \%$ of the 98 taxa are present in all 4 of the most recent floras.
\end{abstract}

Keywords: remnant urban forest; invasive woody plants; arboricultural introductions; long-term; forest composition change; residence time; planting intensity; invasive recognition; urban floras; historical floras 


\section{Introduction}

Invasive plant species are generally not introduced directly to rural forests but instead are first planted in urban areas and later become naturalized in forests surrounding the cities. Considering two invasive plant species with similar abilities to colonize rural forests, if species " $X$ " is introduced to a city much earlier than species "Y", then species "X" can be expected to colonize the rural forests encircling the city before species "Y". The timing of when an invasive plant becomes established in a particular rural forest is related to distance to the urban area. Location further away from a city makes a rural forest relatively less vulnerable to invasion than another rural forest abutting a city. [1,2].

In the United States, a shift in arboricultural plantings away from primarily native species to predominantly alien species began in the 1860s with the large scale introduction of non-native species for plantings in streets, gardens, estates, and parks [3-6]. However, one component of the urban forest was not directly affected by this change in species introductions because forest remnants preserved in parks, natural areas, and forest reserves were not planted and instead spontaneous forest reproduction was permitted to occur and served to supply replacement trees and enabled the first presence of new species [7]. Comparing the relative position of a forest to the source of an invasive woody species, a remnant urban forest is far more vulnerable to being invaded by alien shrubs and trees than rural forests since cities surround remnant urban forests while rural forests surround cities. The vulnerability to invasion is increased over long time periods as additional introductions of the particular invasive woody species as well as other invasive trees and shrubs continue to occur [8].

Biodiversity research in regard to arboricultural introductions and especially invasive species in remnant urban forests must consider both the time and space factors. Magurran and colleagues [9] noted a "long-term dataset in the context of biodiversity is simply the information on the variety ... of species (or other taxonomic units) at one or more locations at a number of points in time." Comparisons of floras from different time periods have formed long-term datasets in biodiversity research to determine changes in the native and non-native components of urban floras in many countries. The research has focused on examining how arboricultural introductions relate to all alien species that have become naturalized in cities rather than only invasive species which cause large scale losses of native species in remnant urban forests [10-15]. Analysis of alien species naturalization has focused on residence time, which depends on the year of introduction to arboriculture, since the longer a species is present in cultivation the greater the opportunity for escape and establishment in the forests of a study region. A second factor is planting intensity, which is based on the year a species is known to have been planted in arboreta, botanical gardens, and parks of the region under study [16-19]. Finally, management of regionally invasive shrubs and trees within a particular state of a region involves acknowledgement of the invasive status of the species at the state level; therefore, differences between regional and state recognition may permit invasion of remnant urban forests [20]. The research question for this study is: how does the residence time, planting intensity, and state level recognition of regional invasive woody taxa relate to long-term invasive trees and shrubs presence in urban remnant forests? 


\section{Methods}

One concern with comparisons of floras across forests regions is differences in growing conditions and ecological relationships with native flora [7]; therefore, this research focuses on one large urban remnant forest in each of four cities (Table 1), which are located in the coastal oak-chestnut region of the United States [21]. Floras associated with the forests were released within four time periods: 1818-1840 [22-25]; 1880-1919 [26-29]; 1993-1996 [30-33]; and 1998-2011 [32,34-36]. The floras from 1818 to 1840 represent the respective cities while the floras from 1998 to 2011 are for the individual remnant urban forests. The 1880 to 1919 floras span the geographic levels of the particular remnant urban forest to the city. Except for the flora that covers the entire valley of Wissahickon Creek instead of just the large remnant urban forest called Wissahickon Creek, the 1993 to 1996 floras are specifically for the remnant urban forests. Nomenclature and growth form follows Hortus Third [37].

Table 1. Urban Forest, longitude, latitude, county, state and size (in ha).

\begin{tabular}{cccccc}
\hline Urban Forest & Longitude & Latitude & City & State & Size/HA \\
\hline Middlesex Fells & $71^{\circ} 06^{\prime} 21^{\prime \prime} \mathrm{W}$ & $42^{\circ} 26^{\prime} 51^{\prime \prime} \mathrm{N}$ & Boston & MA & 400 \\
Pelham Bay & $73^{\circ} 48^{\prime} 28^{\prime \prime} \mathrm{W}$ & $40^{\circ} 51^{\prime} 56^{\prime \prime} \mathrm{N}$ & New York & NY & 1119 \\
Wissahickon Creek & $75^{\circ} 13^{\prime} 09^{\prime \prime} \mathrm{W}$ & $40^{\circ} 07^{\prime} 00^{\prime \prime} \mathrm{N}$ & Philadelphia & PA & 748 \\
Rock Creek & $77^{\circ} 02^{\prime} 47^{\prime \prime} \mathrm{W}$ & $38^{\circ} 58^{\prime} 19^{\prime \prime} \mathrm{N}$ & Washington & DC & 713 \\
\hline
\end{tabular}

The invasive trees and shrubs reported in the United States Mid-Atlantic Exotic Pest Plant Council Plant List [38] encompass the coastal oak-chestnut region of the United States. Residence time for the taxa were based on the date of introduction to arboriculture as listed in the Manual of Cultivated Trees and Shrubs [39]. However, the Manual of Cultivated Trees and Shrubs describes many taxa as "long cultivated" and the date 1575 was assigned to these taxa because the earliest year of introduction to arboriculture given for a taxon in this study is 1576. Following the methods of prior researchers [16-19], planting intensity is based solely on the presence or absence of taxa in the floras of North America, botanical gardens, and parks. Specifically, planting intensity is derived from two time periods with 1811-1818 including the floras of North America and botanical gardens in two cities (New York and Boston) of the study region [40-42] and 1857-1903 from the floras of Central Park, New York, NY and Fairmount Park, Philadelphia, PA [6]. The Pearson's product moment correlation analysis and paired samples, two tailed $t$-tests were performed using PASW Statistics (formerly SPSS) version 17 and the significance level selected was 0.05 .

\section{Results and Discussion}

\subsection{Residence Time and Presence in Floras}

Of the 98 invasive woody taxa in Table 2, 61 are shrubs while 37 are trees. Shrubs have nearly equal percentages in the three time periods spanning the dates of introduction to arboriculture (1575-1750, 1751-1850, and 1851-1950). In contrast, more than half of the trees were introduced in the earliest time period of 1575-1750. Of the 40 taxa classified as introduced to arboriculture during the 1575-1750 period, 33 were described as "long cultivated" in the Manual of Cultivated Trees and 
Shrubs [39] but are designated as 1575 in this analysis. The total for taxa in 1751-1850 and 1851-1950 are nearly equal with 30 and 28 taxa, respectively. The numbers of floras noting taxa are grouped as: none-22 taxa; 1 and 2-22 taxa; 3 and 4-18 taxa; 5 and 6-20 taxa; and greater than 6-16 taxa. Only the final two groups ( 5 and 6 as well as $>6$ ) have at least as many taxa in 1675-1750 as 1751-1850 and 1851-1950 combined as compared to the first three groups of presence in floras having approximately an equal number of taxa in all three time periods. Considering presence only in the most recent flora, the number of taxa in remnant forests is: no forests -28 taxa; 1 forest -21 taxa; 2 forests-22 taxa; 3 forests -9 taxa; and 4 forests-18 taxa.

The tree Robinia pseudoacacia is the only taxon present in all 16 floras, which is probably related to the fact that the species is alien to the Mid-Atlantic region but is not an alien to the United States and was an early arboricultural introduction in 1635. The long cultivated shrub Ligustrum vulgare: is the next most frequently reported taxon (12 floras); is noted in all of the Boston-Middlesex Fells and New York-Pelham Bay floras; but is not indicated as present in the most recent floras for Wissahickon Creek (Philadelphia) and Rock Creek (Washington). The six taxa present in 9 to 11 floras (Prunus avium (11), Lonicera japonica (11), Acer platanoides (10), Morus alba (10), Ailanthus altissima (9), and Pyrus malus (9)) were arboricultural introductions before 1810 but none are present in the first floras of the four cities. There are 8 taxa (Alnus glutinosa, Berberis vulgaris, Ligustrum vulgare, Rhamnus cathartica, Robinia pseudoacacia, Rosa carolina, Rosa micrantha, and Salix alba) present in one or more of the earliest floras for the cities and all eight are in at least one of the most recent floras except for Rosa micrantha. The eight taxa in the 1818-1840 floras were "long cultivated" except for Robinia pseudoacacia and Rosa carolina. Another commonality of Robinia pseudoacacia and Rosa carolina is both are native to the United States but not native to the Mid-Atlantic region which may explain why the Manual of Cultivated Trees and Shrubs [39] lists the arboricultural introduction date for Rosa carolina as 1826 but the 1819 flora for New York indicates the species was naturalized in the city.

The total for invasive woody taxa in the four cities and remnant urban forests increased from the earliest time period (1818-1840) to the most recent time period (1998-2011) with the exception of the decrease from 37 in 1996 to 35 in 2004 for Wissahickon Creek in Philadelphia. This exception can be explained by the 1996 survey encompassing a larger area than the 2004 survey as compared to same area for the remnant urban forests being surveyed for the other three most recent and penultimate floras. The results of a paired two-tailed t-test of the differences between the mean number of invasive shrubs and trees for 1818-1840 and 1880-1919, 1880-1919 and 1993-1996, as well as 1993-1996 and 1998-2011 were significant at the 0.05 level; therefore, the increase in invasive taxa over the four time periods is significant across the region. 
Table 2. Presence of invasive trees and shrubs as listed in the Mid-Atlantic Exotic Pest Plant Council Plant List [38] in the floras for the four remnant urban forests and cities: Middlesex Fells and Boston-1840 [22], 1896 [26], 1993 [30], and 2011 [34]; Pelham Bay and New York-1810 [23], 1880 [27], 1948 [31], and 1998 [31]; Wissahickon Creek and Philadelphia-1818 [24], 1905 [28], 1996 [32], and 2004 [35]; as well as Rock Creek and Washington-1830 [25], 1919 [29], 1995 [33], and 2011 [36]. Species binomials and growth form (tree-T and shrub-S) follow Hortus Third [37]. Year introduced into arboriculture (Year Intro) follows the Manual of Cultivated Trees and Shrubs [38]. Total is the sum of the taxa reported for particular floras and Total Occurrence (Total Occur) is the sum of all occurrences of each taxon.

\begin{tabular}{|c|c|c|c|c|c|c|c|c|c|c|c|c|c|c|c|c|c|c|c|}
\hline \multirow[t]{2}{*}{ Taxa } & \multirow{2}{*}{$\begin{array}{l}\text { Growth } \\
\text { Form }\end{array}$} & \multirow{2}{*}{$\begin{array}{l}\text { Year } \\
\text { Intro }\end{array}$} & \multicolumn{3}{|c|}{$\begin{array}{c}\text { Middlesex Fells } \\
\text { Boston }\end{array}$} & \multirow[b]{2}{*}{2011} & \multicolumn{3}{|c|}{$\begin{array}{c}\text { Pelham Bay } \\
\text { New York }\end{array}$} & \multirow[b]{2}{*}{1998} & \multicolumn{3}{|c|}{$\begin{array}{c}\text { Wissahickon Creek } \\
\text { Philadelphia } \\
\end{array}$} & \multirow[b]{2}{*}{2004} & \multicolumn{3}{|c|}{$\begin{array}{l}\text { Rock Creek } \\
\text { Washington } \\
\end{array}$} & \multirow[b]{2}{*}{2011} & \multirow{2}{*}{$\begin{array}{l}\text { Total } \\
\text { Occu }\end{array}$} \\
\hline & & & 1840 & 1896 & 1993 & & 1819 & 1880 & 1948 & & 1818 & 1905 & 1996 & & 1830 & 1919 & 1995 & & \\
\hline Acer palmatum & $\mathrm{T}$ & 1820 & & & & $\mathrm{X}$ & & & & & & & & $\mathrm{X}$ & & & $\mathrm{X}$ & $\mathrm{X}$ & 4 \\
\hline Acer platanoides & $\mathrm{T}$ & 1770 & & & $\mathrm{X}$ & $\mathrm{X}$ & & & $\mathrm{X}$ & $\mathrm{X}$ & & $\mathrm{X}$ & $\mathrm{X}$ & $\mathrm{X}$ & & $\mathrm{X}$ & $\mathrm{X}$ & $\mathrm{X}$ & 10 \\
\hline Acer pseudoplatanus & $\mathrm{T}$ & 1575 & & & & & & & $\mathrm{X}$ & $\mathrm{X}$ & & & $\mathrm{X}$ & $\mathrm{X}$ & & $\mathrm{X}$ & & $\mathrm{X}$ & 6 \\
\hline Aesculus hippocastanum & $\mathrm{T}$ & 1576 & & & & $\mathrm{X}$ & & & & $\mathrm{X}$ & & $\mathrm{X}$ & $\mathrm{X}$ & $\mathrm{X}$ & & & & & 5 \\
\hline Ailanthus altissima & $\mathrm{T}$ & 1784 & & & $X$ & $\mathrm{X}$ & & & & $\mathrm{X}$ & & $\mathrm{X}$ & $\mathrm{X}$ & $\mathrm{X}$ & & $\mathrm{X}$ & $\mathrm{X}$ & $\mathrm{X}$ & 9 \\
\hline Akebia quinata & $\mathrm{S}$ & 1845 & & & & & & & & & & & $\mathrm{X}$ & $\mathrm{X}$ & & & & & 2 \\
\hline Albizia julibrissin & $\mathrm{T}$ & 1745 & & & & & & & & $\mathrm{X}$ & & & & & & & $\mathrm{X}$ & $\mathrm{X}$ & 3 \\
\hline Alnus glutinosa & $\mathrm{T}$ & 1575 & & & $\mathrm{X}$ & $\mathrm{X}$ & & & $\mathrm{X}$ & $\mathrm{X}$ & $\mathrm{X}$ & & $\mathrm{X}$ & & & & $\mathrm{X}$ & $\mathrm{X}$ & 8 \\
\hline Aralia elata & $\mathrm{T}$ & 1830 & & & & $\mathrm{X}$ & & & & & & & & $\mathrm{X}$ & & & & & 2 \\
\hline Berberis thunbergii & $\mathrm{S}$ & 1864 & & & $\mathrm{X}$ & $\mathrm{X}$ & & & $\mathrm{X}$ & $\mathrm{X}$ & & & $\mathrm{X}$ & $\mathrm{X}$ & & & $\mathrm{X}$ & $\mathrm{X}$ & 8 \\
\hline Berberis vulgaris & $\mathrm{S}$ & 1575 & $\mathrm{X}$ & $\mathrm{X}$ & $\mathrm{X}$ & $\mathrm{X}$ & & $\mathrm{X}$ & & & & $\mathrm{X}$ & & & & $\mathrm{X}$ & & & 7 \\
\hline Betula pendula & $\mathrm{T}$ & 1575 & & & & & & & & & & & & & & & & & 0 \\
\hline Broussonetia papyrifera & $\mathrm{T}$ & 1750 & & & & & & & $\mathrm{X}$ & $X$ & & $\mathrm{X}$ & $\mathrm{X}$ & $\mathrm{X}$ & & $\mathrm{X}$ & & & 6 \\
\hline Buddleja davidii & $\mathrm{S}$ & 1890 & & & & & & & & & & & & & & & & & 0 \\
\hline Catalpa ovata & $\mathrm{T}$ & 1849 & & & & & & & & & & & & & & $\mathrm{X}$ & & & 1 \\
\hline Catalpa speciosa & $\mathrm{T}$ & 1754 & & & & & & & & $\mathrm{X}$ & & & & & & & & & 1 \\
\hline Celastrus orbiculatus & $\mathrm{S}$ & 1860 & & & & $\mathrm{X}$ & & & & $\mathrm{X}$ & & & $\mathrm{X}$ & $\mathrm{X}$ & & & $\mathrm{X}$ & $\mathrm{X}$ & 6 \\
\hline Deutzia scabra & $\mathrm{S}$ & 1822 & & & & & & & & & & & $\mathrm{X}$ & $\mathrm{X}$ & & & & $\mathrm{X}$ & 3 \\
\hline Elaeagnus angustifolia & $\mathrm{S}$ & 1575 & & & & & & & & $\mathrm{X}$ & & & & & & & & & 1 \\
\hline Elaeagnus pungens & $\mathrm{S}$ & 1830 & & & & & & & & & & & & & & & $\mathrm{X}$ & $X$ & 2 \\
\hline Elaeagnus umbellata & $\mathrm{S}$ & 1830 & & & & & & & $\mathrm{X}$ & $\mathrm{X}$ & & & & & & & $\mathrm{X}$ & $\mathrm{X}$ & 4 \\
\hline Euonymus alatus & $\mathrm{S}$ & 1860 & & & $\mathrm{X}$ & $\mathrm{X}$ & & & & $\mathrm{X}$ & & & $\mathrm{X}$ & $\mathrm{X}$ & & & & $\mathrm{X}$ & 6 \\
\hline
\end{tabular}


Table 2. Cont.

\begin{tabular}{|c|c|c|c|c|c|c|c|c|c|c|c|c|c|c|c|c|c|c|c|}
\hline \multirow[t]{2}{*}{ Taxa } & \multirow{2}{*}{$\begin{array}{c}\text { Growth } \\
\text { Form }\end{array}$} & \multirow{2}{*}{$\begin{array}{l}\text { Year } \\
\text { Intro }\end{array}$} & \multicolumn{3}{|c|}{$\begin{array}{l}\text { Middlesex Fells } \\
\text { Boston }\end{array}$} & \multirow[b]{2}{*}{2011} & \multicolumn{3}{|c|}{$\begin{array}{c}\text { Pelham Bay } \\
\text { New York }\end{array}$} & \multirow[b]{2}{*}{1998} & \multicolumn{3}{|c|}{$\begin{array}{c}\text { Wissahickon Creek } \\
\text { Philadelphia }\end{array}$} & \multirow[b]{2}{*}{2004} & \multicolumn{3}{|c|}{$\begin{array}{l}\text { Rock Creek } \\
\text { Washington }\end{array}$} & \multirow[b]{2}{*}{2011} & \multirow{2}{*}{$\begin{array}{l}\text { Total } \\
\text { Occur }\end{array}$} \\
\hline & & & 1840 & 1896 & 1993 & & 1819 & 1880 & 1948 & & 1818 & 1905 & 1996 & & 1830 & 1919 & 1995 & & \\
\hline Euonymus europaeus & S & 1575 & & & & $\mathrm{X}$ & & & $\mathrm{X}$ & $\mathrm{X}$ & & $\mathrm{X}$ & $\mathrm{X}$ & & & & & & 5 \\
\hline Euonymus fortunei & S & 1907 & & & & $\mathrm{X}$ & & & & $\mathrm{X}$ & & & & $\mathrm{X}$ & & & $\mathrm{X}$ & $\mathrm{X}$ & 5 \\
\hline Hedera helix & $\mathrm{S}$ & 1575 & & & & $\mathrm{X}$ & & & & $\mathrm{X}$ & & & $\mathrm{X}$ & $\mathrm{X}$ & & $\mathrm{X}$ & $\mathrm{X}$ & $\mathrm{X}$ & 7 \\
\hline Hibiscus syriacus & $\mathrm{S}$ & 1575 & & & & & & & & $\mathrm{X}$ & & $\mathrm{X}$ & $\mathrm{X}$ & & & $\mathrm{X}$ & $\mathrm{X}$ & $X$ & 6 \\
\hline Ilex aquifolium & $\mathrm{S}$ & 1575 & & & & & & & & & & & & & & & & & 0 \\
\hline Ilex crenata & $\mathrm{S}$ & 1864 & & & & & & & & & & & & $\mathrm{X}$ & & & $\mathrm{X}$ & $\mathrm{X}$ & 3 \\
\hline Kerria japonica & $\mathrm{S}$ & 1834 & & & & $\mathrm{X}$ & & & & & & & & & & & & & 1 \\
\hline Lagerstroemia indica & $\mathrm{S}$ & 1747 & & & & & & & & & & & & & & & & & 0 \\
\hline Ligustrum amurense & $\mathrm{S}$ & 1860 & & & & & & & & & & & & & & & & & 0 \\
\hline Ligustrum obtusifolium & $\mathrm{S}$ & 1860 & & & & $\mathrm{X}$ & & & & & & & $\mathrm{X}$ & $\mathrm{X}$ & & & $\mathrm{X}$ & $\mathrm{X}$ & 5 \\
\hline Ligustrum ovalifolium & $\mathrm{S}$ & 1847 & & & & & & & & & & & & & & & $\mathrm{X}$ & $\mathrm{X}$ & 2 \\
\hline Ligustrum sinense & $\mathrm{S}$ & 1852 & & & & & & & & & & & & & & & & & 0 \\
\hline Ligustrum vulgare & $\mathrm{S}$ & 1575 & $\mathrm{X}$ & $\mathrm{X}$ & $\mathrm{X}$ & $\mathrm{X}$ & $\mathrm{X}$ & $\mathrm{X}$ & $\mathrm{X}$ & $\mathrm{X}$ & $\mathrm{X}$ & $\mathrm{X}$ & $\mathrm{X}$ & & & $\mathrm{X}$ & & & 12 \\
\hline Lonicera fragrantissima & $\mathrm{S}$ & 1845 & & & & & & & & $\mathrm{X}$ & & & & & & & & $\mathrm{X}$ & 2 \\
\hline Lonicera japonica & $\mathrm{S}$ & 1806 & & & $\mathrm{X}$ & $\mathrm{X}$ & & & $\mathrm{X}$ & $\mathrm{X}$ & & $\mathrm{X}$ & $\mathrm{X}$ & $\mathrm{X}$ & & $\mathrm{X}$ & $\mathrm{X}$ & $\mathrm{X}$ & 10 \\
\hline Lonicera maackii & $\mathrm{S}$ & 1855 & & & & & & & & & & & $\mathrm{X}$ & $\mathrm{X}$ & & & $\mathrm{X}$ & $\mathrm{X}$ & 4 \\
\hline Lonicera morrowii & $\mathrm{S}$ & 1875 & & & & $\mathrm{X}$ & & & & $\mathrm{X}$ & & & & $\mathrm{X}$ & & & $\mathrm{X}$ & $\mathrm{X}$ & 5 \\
\hline Lonicera standishii & $\mathrm{S}$ & 1845 & & & & & & & & & & & & & & & & & 0 \\
\hline Lonicera tatarica & $\mathrm{S}$ & 1752 & & & & $\mathrm{X}$ & & & & & & $\mathrm{X}$ & $\mathrm{X}$ & & & & & & 3 \\
\hline Lonicera $x$ bella & $\mathrm{S}$ & 1878 & & & & $\mathrm{X}$ & & & & $\mathrm{X}$ & & & & & & & & & 2 \\
\hline Lonicera xylosteum & $\mathrm{S}$ & 1575 & & & & $\mathrm{X}$ & & & & & & & & & & & & $\mathrm{X}$ & 2 \\
\hline Maclura pomifera & $\mathrm{T}$ & 1818 & & & & & & & & $\mathrm{X}$ & & & $\mathrm{X}$ & & & $\mathrm{X}$ & $\mathrm{X}$ & $\mathrm{X}$ & 5 \\
\hline Melia azedarach & $\mathrm{T}$ & 1600 & & & & & & & & & & & & & & & & & 0 \\
\hline Morus alba & $\mathrm{T}$ & 1575 & & & & $\mathrm{X}$ & & $\mathrm{X}$ & $\mathrm{X}$ & $\mathrm{X}$ & & $\mathrm{X}$ & $\mathrm{X}$ & $\mathrm{X}$ & & $\mathrm{X}$ & $\mathrm{X}$ & $\mathrm{X}$ & 10 \\
\hline Paulownia tomentosa & $\mathrm{T}$ & 1834 & & & & & & & $\mathrm{X}$ & $\mathrm{X}$ & & $\mathrm{X}$ & $\mathrm{X}$ & $\mathrm{X}$ & & $\mathrm{X}$ & $\mathrm{X}$ & $\mathrm{X}$ & 8 \\
\hline Phellodendron amurense & $\mathrm{T}$ & 1856 & & & & & & & & & & & & & & & & & 0 \\
\hline Phellodendron japonica & $\mathrm{T}$ & 1863 & & & & & & & & & & & & & & & & & 0 \\
\hline Picea abies & $\mathrm{T}$ & 1575 & & $\mathrm{X}$ & $\mathrm{X}$ & $\mathrm{X}$ & & & & $\mathrm{X}$ & & & & $\mathrm{X}$ & & & & $\mathrm{X}$ & 6 \\
\hline
\end{tabular}


Table 2. Cont.

\begin{tabular}{|c|c|c|c|c|c|c|c|c|c|c|c|c|c|c|c|c|c|c|c|}
\hline \multirow[t]{2}{*}{ Taxa } & \multirow{2}{*}{$\begin{array}{l}\text { Growth } \\
\text { Form }\end{array}$} & \multirow{2}{*}{$\begin{array}{l}\text { Year } \\
\text { Intro }\end{array}$} & \multicolumn{3}{|c|}{$\begin{array}{c}\text { Middlesex Fells } \\
\text { Boston }\end{array}$} & \multirow[b]{2}{*}{2011} & \multicolumn{3}{|c|}{$\begin{array}{c}\text { Pelham Bay } \\
\text { New York }\end{array}$} & \multirow[b]{2}{*}{1998} & \multicolumn{3}{|c|}{$\begin{array}{c}\text { Wissahickon Creek } \\
\text { Philadelphia }\end{array}$} & \multirow[b]{2}{*}{2004} & \multicolumn{3}{|c|}{$\begin{array}{l}\text { Rock Creek } \\
\text { Washington }\end{array}$} & \multirow[b]{2}{*}{2011} & \multirow{2}{*}{$\begin{array}{l}\text { Total } \\
\text { Occur }\end{array}$} \\
\hline & & & 1840 & 1896 & 1993 & & 1819 & 1880 & 1948 & & 1818 & 1905 & 1996 & & 1830 & 1919 & 1995 & & \\
\hline Pinus sylvestris & $\mathrm{T}$ & 1575 & & & & $\mathrm{X}$ & & & $\mathrm{X}$ & $\mathrm{X}$ & & & $\mathrm{X}$ & $\mathrm{X}$ & & & & & 5 \\
\hline Pinus thunbergii & $\mathrm{T}$ & 1855 & & & & & & & & & & & & $\mathrm{X}$ & & & $\mathrm{X}$ & & 2 \\
\hline Populus alba & $\mathrm{T}$ & 1575 & & & & & & $\mathrm{X}$ & $\mathrm{X}$ & $X$ & & $\mathrm{X}$ & & & & $\mathrm{X}$ & & & 5 \\
\hline Prunus avium & $\mathrm{T}$ & 1625 & & $\mathrm{X}$ & $\mathrm{X}$ & $\mathrm{X}$ & & & $\mathrm{X}$ & $\mathrm{X}$ & & $\mathrm{X}$ & $\mathrm{X}$ & $\mathrm{X}$ & & $\mathrm{X}$ & $\mathrm{X}$ & $\mathrm{X}$ & 11 \\
\hline Prunus cerasus & $\mathrm{S}$ & 1575 & & $\mathrm{X}$ & $\mathrm{X}$ & $\mathrm{X}$ & & & & & & & & & & $\mathrm{X}$ & & & 4 \\
\hline Prunus mahaleb & $\mathrm{T}$ & 1575 & & & & & & & & & & $\mathrm{X}$ & & & & $\mathrm{X}$ & & & 2 \\
\hline Prunus padus & $\mathrm{T}$ & 1575 & & & & & & & & & & & & & & & & & 0 \\
\hline Prunus persica & $\mathrm{T}$ & 1575 & & & & & & & $\mathrm{X}$ & $\mathrm{X}$ & & & $\mathrm{X}$ & & & & & & 3 \\
\hline Pueraria lobata & $\mathrm{S}$ & 1855 & & & & & & & & $\mathrm{X}$ & & & & & & $\mathrm{X}$ & $\mathrm{X}$ & $X$ & 4 \\
\hline Pyrus calleryana & $\mathrm{T}$ & 1908 & & & & & & & & $\mathrm{X}$ & & & & & & & & & 1 \\
\hline Pyrus malus & $\mathrm{T}$ & 1575 & & $\mathrm{X}$ & $\mathrm{X}$ & $\mathrm{X}$ & & & $\mathrm{X}$ & $\mathrm{X}$ & & $\mathrm{X}$ & $\mathrm{X}$ & $\mathrm{X}$ & & $\mathrm{X}$ & & & 9 \\
\hline Quercus acutissima & $\mathrm{T}$ & 1862 & & & & & & & & & & & & & & & $\mathrm{X}$ & $\mathrm{X}$ & 2 \\
\hline Rhamnus cathartica & $\mathrm{S}$ & 1575 & $\mathrm{X}$ & $\mathrm{X}$ & $\mathrm{X}$ & $\mathrm{X}$ & & & & $\mathrm{X}$ & & $\mathrm{X}$ & & & & & & & 6 \\
\hline Rhamnus frangula & S & 1575 & & & & & & & $\mathrm{X}$ & $\mathrm{X}$ & & & & & & & & & 2 \\
\hline Rhodotypos scandens & $\mathrm{S}$ & 1866 & & & & $\mathrm{X}$ & & & $\mathrm{X}$ & $\mathrm{X}$ & & & $\mathrm{X}$ & $\mathrm{X}$ & & & $\mathrm{X}$ & $\mathrm{X}$ & 7 \\
\hline Ribes rubrum & S & 1575 & & $\mathrm{X}$ & $\mathrm{X}$ & $\mathrm{X}$ & & & $\mathrm{X}$ & & & $\mathrm{X}$ & & & & & & & 5 \\
\hline Robinia hispida & $\mathrm{S}$ & 1758 & & & & $\mathrm{X}$ & & & & & & $\mathrm{X}$ & & & & & & & 2 \\
\hline Robinia pseudoacacia & $\mathrm{T}$ & 1635 & $\mathrm{X}$ & $\mathrm{X}$ & $\mathrm{X}$ & $\mathrm{X}$ & $\mathrm{X}$ & $\mathrm{X}$ & $\mathrm{X}$ & $\mathrm{X}$ & $\mathrm{X}$ & $\mathrm{X}$ & $\mathrm{X}$ & $\mathrm{X}$ & $\mathrm{X}$ & $\mathrm{X}$ & $\mathrm{X}$ & $\mathrm{X}$ & 16 \\
\hline Rosa bracteata & $\mathrm{S}$ & 1793 & & & & & & & & & & & & & & & & & 0 \\
\hline Rosa canina & $\mathrm{S}$ & 1575 & & & & & & & & & & $\mathrm{X}$ & & & & $\mathrm{X}$ & & & 2 \\
\hline Rosa carolina & S & 1826 & & & $\mathrm{X}$ & $\mathrm{X}$ & $\mathrm{X}$ & $\mathrm{X}$ & $\mathrm{X}$ & & & $\mathrm{X}$ & $\mathrm{X}$ & & & & $\mathrm{X}$ & & 8 \\
\hline Rosa gallica & S & 1575 & & & & & & & & & & & & & & & & & 0 \\
\hline Rosa micrantha & S & 1575 & $\mathrm{X}$ & & & & & $\mathrm{X}$ & & & & & & & & & & & 2 \\
\hline Rosa multiflora & S & 1868 & & & & $\mathrm{X}$ & & & & $\mathrm{X}$ & & & & $\mathrm{X}$ & & & $\mathrm{X}$ & $\mathrm{X}$ & 5 \\
\hline Rosa rugosa & S & 1845 & & & & $\mathrm{X}$ & & & $\mathrm{X}$ & $\mathrm{X}$ & & & & & & & & & 3 \\
\hline Rosa wichuraiana & S & 1891 & & & & & & & & & & & & & & & & & 0 \\
\hline Rubus armeniacus & $\mathrm{S}$ & 1770 & & & & & & & & & & & & & & & & & 0 \\
\hline Rubus bifrons & $\mathrm{S}$ & 1818 & & & & & & & & & & & & & & & & & 0 \\
\hline
\end{tabular}


Table 2. Cont.

\begin{tabular}{|c|c|c|c|c|c|c|c|c|c|c|c|c|c|c|c|c|c|c|c|}
\hline \multirow[t]{2}{*}{ Taxa } & \multirow[t]{2}{*}{$\begin{array}{c}\text { Growth } \\
\text { Form }\end{array}$} & \multirow[t]{2}{*}{$\begin{array}{l}\text { Year } \\
\text { Intro }\end{array}$} & \multicolumn{3}{|c|}{$\begin{array}{c}\text { Middlesex Fells } \\
\text { Boston } \\
\end{array}$} & \multirow[b]{2}{*}{2011} & \multicolumn{3}{|c|}{$\begin{array}{c}\text { Pelham Bay } \\
\text { New York }\end{array}$} & \multirow[b]{2}{*}{1998} & \multicolumn{3}{|c|}{$\begin{array}{c}\text { Wissahickon Creek } \\
\text { Philadelphia } \\
\end{array}$} & \multirow[b]{2}{*}{2004} & \multicolumn{3}{|c|}{$\begin{array}{l}\text { Rock Creek } \\
\text { Washington } \\
\end{array}$} & \multirow[b]{2}{*}{2011} & \multirow{2}{*}{$\begin{array}{l}\text { Total } \\
\text { Occur }\end{array}$} \\
\hline & & & 1840 & 1896 & 1993 & & 1819 & 1880 & 1948 & & 1818 & 1905 & 1996 & & 1830 & 1919 & 1995 & & \\
\hline Rubus illecebrosus & $\mathrm{S}$ & 1895 & & & & & & & & & & & & & & & & & 0 \\
\hline Rubus laciniatus & $\mathrm{S}$ & 1770 & & & & & & & $\mathrm{X}$ & $\mathrm{X}$ & & $\mathrm{X}$ & $\mathrm{X}$ & & & & & & 4 \\
\hline Rubus phoenicolasius & $\mathrm{S}$ & 1876 & & & & $X$ & & & $\mathrm{X}$ & $\mathrm{X}$ & & & $\mathrm{X}$ & $\mathrm{X}$ & & & $X$ & $\mathrm{X}$ & 7 \\
\hline Salix alba & $\mathrm{T}$ & 1575 & & & & $\mathrm{X}$ & & $\mathrm{X}$ & & $\mathrm{X}$ & $\mathrm{X}$ & $\mathrm{X}$ & & & & $X$ & & & 6 \\
\hline Salix caprea & $\mathrm{T}$ & 1575 & & & & & & & & & & & $\mathrm{X}$ & & & & & & 1 \\
\hline Salix cinerea & $\mathrm{S}$ & 1575 & & & & & & & & & & & & & & & & & 0 \\
\hline Salix fragilis & $\mathrm{T}$ & 1575 & & & & & & $\mathrm{X}$ & & $\mathrm{X}$ & & & $\mathrm{X}$ & & & $X$ & & & 4 \\
\hline Salix pentandra & $\mathrm{S}$ & 1575 & & & & & & & & & & & & & & & & & 0 \\
\hline Salix purpurea & $\mathrm{S}$ & 1575 & & $\mathrm{X}$ & & & & & & & & $\mathrm{X}$ & $\mathrm{X}$ & & & & & & 3 \\
\hline Salix $x$ sepulcralis & $\mathrm{T}$ & 1864 & & & & & & & & & & & & & & & & & 0 \\
\hline Sapium sebiferum & $\mathrm{T}$ & 1850 & & & & & & & & & & & & & & & & & 0 \\
\hline Taxus cuspidata & $\mathrm{S}$ & 1855 & & & & $\mathrm{X}$ & & & & $\mathrm{X}$ & & & & & & & & & 2 \\
\hline Ulmus parvifolia & $\mathrm{T}$ & 1794 & & & & & & & & & & & & $\mathrm{X}$ & & & $\mathrm{X}$ & $\mathrm{X}$ & 3 \\
\hline Ulmus pumila & $\mathrm{T}$ & 1860 & & & & & & & & $X$ & & & & & & & & & 1 \\
\hline Viburnum dilatatum & $\mathrm{S}$ & 1845 & & & & $X$ & & & $X$ & $\mathrm{X}$ & & & & $X$ & & & $\mathrm{X}$ & $X$ & 6 \\
\hline Viburnum opulus & $\mathrm{S}$ & 1575 & & & & $\mathrm{X}$ & & $X$ & & $\mathrm{X}$ & & & $\mathrm{X}$ & & & & & & 4 \\
\hline Viburnum plicatum & $\mathrm{S}$ & 1865 & & & & & & & & & & & & $X$ & & & $X$ & $X$ & 3 \\
\hline Viburnum sieboldii & $\mathrm{S}$ & 1880 & & & & & & & & $X$ & & & $\mathrm{X}$ & $\mathrm{X}$ & & & & & 3 \\
\hline Wisteria floribunda & $\mathrm{S}$ & 1830 & & & & & & & & & & & & & & & & & 0 \\
\hline Wisteria sinensis & $\mathrm{S}$ & 1816 & & & & $X$ & & & & $X$ & & & $X$ & $\mathrm{X}$ & & & $\mathrm{X}$ & $X$ & 6 \\
\hline Total & 98 & & 5 & 10 & 16 & 41 & 3 & 10 & 25 & 49 & 3 & 25 & 37 & 35 & 1 & 23 & 34 & 38 & 355 \\
\hline
\end{tabular}


The relationship between residence time (date of introduction to arboriculture) and the number of floras containing the 98 taxa was analyzed by calculating a Pearson product moment correlation coefficient, which is not significant at the 0.05 level. Instead of the total number of floras, the number of cities containing the 98 taxa regardless of the time period when the taxa were reported was analyzed by calculating a Pearson product moment correlation coefficient, which also is not significant at the 0.05 level. A third Pearson product moment correlation coefficient was calculated with the total for presence in the most recent flora for the four remnant forests and residence time, which yet again reveals a non-significant correlation at the 0.05 level. The lack of significant correlations could be caused by the $22 \%$ of the taxa not being present in even one of the 16 floras as well as $34 \%$ of the taxa being dated as 1575 because the Manual of Cultivated Trees and Shrubs [39] only indicates the taxa are "long cultivated" instead of giving a specific year for introduction to arboriculture.

As expected from the literature on naturalization of alien species in cities [10-20], the number of invasive species significantly increased over the four time periods for the floras of the four cities and remnant urban forests. In sharp contrast, the correlation analysis did not provide support for the existence of a relationship between residence time and number of presences in floras as suggested by the literature from cities in Europe and Australia [16-19]. Considering the distribution of presences of invasive shrubs and trees in the 16 floras, two possible explanations are put forth for the no significant correlations: (1) the dates of introduction to arboriculture provided by the Manual of Cultivated Trees and Shrubs are not representative of introduction to arboriculture in the study region; and (2) the broader group of alien plant species in the European and Australian studies [16-19] have different or more varied modes of naturalization than the invasive shrubs and trees of the Mid-Atlantic Exotic Pest Plant Council Plant List [38]. This analysis did reveal that examining the earliest urban floras encompassing the areas of the modern remnant urban forests serves to identify invasive woody taxa that are recognized as common across the forest region. One critical point is clear within the study region, with only $18 \%$ of the regional invasive woody taxa being present in all 4 of the most recent floras for the remnant urban forests there is great potential for an increase in presence of invasive trees and shrubs in the future.

\subsection{Planting Intensity and Presence in Floras}

The North American flora from 1818 [41] contains 21 invasive woody taxa from the Mid-Atlantic Exotic Pest Plant Council Plant List [38] including 8 trees and 13 shrubs (Table 3). Columbia University's Elgin Botanical Garden flora in 1811 [40] had 25 invasive woody taxa (11 trees and 14 shrubs) as compared to Harvard University's Botanical Garden flora in 1818 [42] having 15 invasive woody taxa (6 trees and 9 shrubs). Just Hibiscus syriacus, Ligustrum vulgare, Melia azedarach, Morus alba, Ribes rubrum, Robinia hispida, Robinia pseudoacacia, Rosa carolina, and Viburnum opulus are present in all three 1811-1818 floras but Robinia pseudoacacia and Rosa carolina are not alien to North America. There are a total of 32 taxa (14 trees and 18 shrubs) that occur in at least one of the North American and Botanical Gardens floras. Only Ilex aquifolium, Lagerstroemia indica, Melia azedarach, Prunus padus, Rosa gallica, and Salix pentandra are listed in the three 1811-1818 floras but not reported in any of the floras of the four cities and remnant urban forests. The numbers of floras from cities and remnant urban forests noting the taxa from the floras of 
1811-1818 are grouped as: none-6 taxa; 1 and 2-3 taxa; 3 and 4-2 taxa; 5 and 6-12 taxa; and greater than 6-9 taxa. In comparison to the entire 98 invasive trees and shrubs which had only $37 \%$ of the taxa in 5 or more of the city and remnant urban forest floras, the 1811-1818 floras have $66 \%$. The Pearson product moment correlation between the number of the 16 floras containing an invasive woody taxon and the number of 1811-1818 floras containing the woody taxon is significant at the 0.05 level. Similarly, the Pearson product moment correlation between the number of the 4 most recent floras containing an invasive woody taxon and the number of 1811-1818 floras containing the woody taxon is significant at the 0.05 level.

The floras for Central Park [6] have 74 invasive woody taxa (30 trees and 44 shrubs) while the floras for Fairmount Park [6] have 57 invasive woody taxa (27 trees and 30 shrubs). Central Park and Fairmount Park have 52 invasive woody taxa in common ( 24 trees and 28 shrubs) and have a total of 79 different invasive woody taxa. The numbers of floras from cities and remnant urban forests noting the taxa from the Central Park and Fairmount Park floras are grouped as: none-13 taxa; 1 and 2-18 taxa; 3 and 4-17 taxa; 5 and 6-16 taxa; and greater than 6-15 taxa. Of the 98 regional invasive woody taxa, $37 \%$ of the taxa are in 5 or more of the city and remnant urban forest floras, while the Central and Fairmount Parks floras have 39\%. The Pearson product moment correlation between the number of the 16 floras containing an invasive woody taxon and whether the floras for Central Park and Fairmount Park (correlation based on 0 indicates not in the floras of either park; 1 indicates in floras of one or the other park; and 2 indicates in floras of both parks) containing the woody taxon as an invasive is significant at the 0.05 level. Likewise, the Pearson product moment correlation between the number of the 4 most recent floras containing an invasive woody taxon and whether the floras for Central Park and Fairmount Park containing the woody taxon as an invasive is significant at the 0.05 level. Planting intensity being a better correlate with presence in the floras of the coastal oak-chestnut forest of the United States over the long-term than residence time reflects the patterns in Europe and Australia [16-19]. 
Table 3. Presence of invasive trees and shrubs as listed in the Mid-Atlantic Exotic Pest Plant Council Plant List [38] in floras: North America of 1818 [41]; Elgin Botanical Gardens, New York of 1811 [40]; Harvard Botanical Gardens, Boston of 1818 [42]; Central Park, New York from 1857 to 1903 [6]; and Fairmount Park, Philadelphia from 1868 to 1880 [6]. State level invasive taxon designation is for Massachusetts (MA), New York (NY), Pennsylvania (PA), and the District of Columbia (DC) [38]. Species binomials and growth form (tree-T and shrub-S) follow Hortus Third [37]. Year introduced into arboriculture follows the Manual of Cultivated Trees and Shrubs [39]. Total is the sum of the taxa reported for particular floras as well as the state level designations as an invasive and Total Occurrence (Total Occur) is the sum of all occurrences of each taxon in the four state designations.

\begin{tabular}{|c|c|c|c|c|c|c|c|c|c|c|c|c|}
\hline Taxa & $\begin{array}{l}\text { Growth } \\
\text { Form }\end{array}$ & $\begin{array}{c}\text { Year } \\
\text { Introduced }\end{array}$ & $\begin{array}{c}\text { North } \\
\text { America } \\
1818\end{array}$ & $\begin{array}{l}\text { Elgin } \\
1811\end{array}$ & $\begin{array}{c}\text { Harvard } \\
1818\end{array}$ & $\begin{array}{c}\text { Central } \\
1857-1903\end{array}$ & $\begin{array}{l}\text { Fairmount } \\
1868-1880\end{array}$ & MA & NY & PA & DC & $\begin{array}{l}\text { Total } \\
\text { Occur }\end{array}$ \\
\hline Acer palmatum & $\mathrm{T}$ & 1820 & & & & 1863 & 1880 & & & & $\mathrm{X}$ & 0 \\
\hline Acer platanoides & $\mathrm{T}$ & 1770 & & & & 1863 & 1868 & $\mathrm{X}$ & $\mathrm{X}$ & $X$ & $\mathrm{X}$ & 4 \\
\hline Acer pseudoplatanus & $\mathrm{T}$ & 1575 & & & $\mathrm{X}$ & 1863 & 1868 & & & $\mathrm{X}$ & & 1 \\
\hline Aesculus hippocastanum & $\mathrm{T}$ & 1576 & & $\mathrm{X}$ & $\mathrm{X}$ & 1857 & 1868 & & & $X$ & & 1 \\
\hline Ailanthus altissima & $\mathrm{T}$ & 1784 & & & & 1857 & 1868 & $X$ & $X$ & $\mathrm{X}$ & $X$ & 4 \\
\hline Akebia quinata & $\mathrm{S}$ & 1845 & & & & 1873 & 1880 & & & $\mathrm{X}$ & $\mathrm{X}$ & 2 \\
\hline Albizia julibrissin & $\mathrm{T}$ & 1745 & & & & & 1880 & $\mathrm{X}$ & & & $\mathrm{X}$ & 2 \\
\hline Alnus glutinosa & $\mathrm{T}$ & 1575 & $\mathrm{X}$ & & & 1863 & 1880 & & $\mathrm{X}$ & $\mathrm{X}$ & & 2 \\
\hline Aralia elata & $\mathrm{T}$ & 1830 & & & & 1903 & & & & $\mathrm{X}$ & & 1 \\
\hline Berberis thunbergii & $\mathrm{S}$ & 1864 & & & & 1903 & & $\mathrm{X}$ & $\mathrm{X}$ & $\mathrm{X}$ & $\mathrm{X}$ & 4 \\
\hline Berberis vulgaris & $\mathrm{S}$ & 1575 & $X$ & $\mathrm{X}$ & & 1857 & 1868 & $X$ & $\mathrm{X}$ & $X$ & & 3 \\
\hline Betula pendula & $\mathrm{T}$ & 1575 & & & & 1863 & 1880 & & & & & 0 \\
\hline Broussonetia papyrifera & $\mathrm{T}$ & 1750 & $\mathrm{X}$ & $\mathrm{X}$ & & 1857 & 1868 & & & $X$ & $X$ & 2 \\
\hline Buddleja davidii & $\mathrm{S}$ & 1890 & & & & & & & & $\mathrm{X}$ & & 1 \\
\hline Catalpa ovata & $\mathrm{T}$ & 1849 & & & & 1863 & 1880 & $\mathrm{X}$ & & & & 1 \\
\hline Catalpa speciosa & $\mathrm{T}$ & 1754 & & & & 1903 & 1880 & & & & & 0 \\
\hline Celastrus orbiculatus & $\mathrm{S}$ & 1860 & & & & & & $\mathrm{X}$ & $\mathrm{X}$ & $X$ & $\mathrm{X}$ & 4 \\
\hline Deutzia scabra & $\mathrm{S}$ & 1822 & & & & 1863 & 1868 & & & $\mathrm{X}$ & $\mathrm{X}$ & 2 \\
\hline Elaeagnus angustifolia & $\mathrm{S}$ & 1575 & & & & 1863 & 1880 & & $\mathrm{X}$ & $\mathrm{X}$ & $\mathrm{X}$ & 3 \\
\hline Elaeagnus pungens & $\mathrm{S}$ & 1830 & & & & & & & & & & 0 \\
\hline Elaeagnus umbellate & $\mathrm{S}$ & 1830 & & & & 1863 & 1880 & & $\mathrm{X}$ & $\mathrm{X}$ & $\mathrm{X}$ & 3 \\
\hline Euonymus alatus & $\mathrm{S}$ & 1860 & & & & & & $\mathrm{X}$ & & $\mathrm{X}$ & & 2 \\
\hline
\end{tabular}


Table 3. Cont.

\begin{tabular}{|c|c|c|c|c|c|c|c|c|c|c|c|c|}
\hline Taxa & $\begin{array}{c}\text { Growth } \\
\text { Form }\end{array}$ & $\begin{array}{c}\text { Year } \\
\text { Introduced }\end{array}$ & $\begin{array}{c}\text { North } \\
\text { America } \\
1818\end{array}$ & $\begin{array}{l}\text { Elgin } \\
1811\end{array}$ & $\begin{array}{c}\text { Harvard } \\
1818\end{array}$ & $\begin{array}{c}\text { Central } \\
1857-1903\end{array}$ & $\begin{array}{l}\text { Fairmount } \\
1868-1880\end{array}$ & MA & NY & PA & DC & $\begin{array}{l}\text { Total } \\
\text { Occur }\end{array}$ \\
\hline Euonymus europaeus & $\mathrm{S}$ & 1575 & & $\mathrm{X}$ & $\mathrm{X}$ & 1863 & 1880 & $\mathrm{X}$ & & & & 1 \\
\hline Euonymus fortune & $\mathrm{S}$ & 1907 & & & & 1873 & & & & & $\mathrm{X}$ & 1 \\
\hline Hedera helix & $\mathrm{S}$ & 1575 & & $\mathrm{X}$ & & 1863 & & & & $\mathrm{X}$ & $\mathrm{X}$ & 2 \\
\hline Hibiscus syriacus & $\mathrm{S}$ & 1575 & $\mathrm{X}$ & $\mathrm{X}$ & $\mathrm{X}$ & 1857 & 1880 & & & $X$ & $\mathrm{X}$ & 2 \\
\hline Ilex aquifolium & $\mathrm{S}$ & 1575 & $\mathrm{X}$ & $\mathrm{X}$ & & 1863 & 1880 & & & & & 0 \\
\hline Ilex crenata & $\mathrm{S}$ & 1864 & & & & 1903 & 1880 & & & & $\mathrm{X}$ & 1 \\
\hline Kerria japonica & $\mathrm{S}$ & 1834 & & & & 1873 & 1868 & & & & & 0 \\
\hline Lagerstroemia indica & $\mathrm{S}$ & 1747 & & $\mathrm{X}$ & & & 1880 & & & & & 0 \\
\hline Ligustrum amurense & $\mathrm{S}$ & 1860 & & & & & & & & & & 0 \\
\hline Ligustrum obtusifolium & $\mathrm{S}$ & 1860 & & & & & & & & $\mathrm{X}$ & $\mathrm{X}$ & 2 \\
\hline Ligustrum ovalifolium & $\mathrm{S}$ & 1847 & & & & 1873 & & & & $\mathrm{X}$ & & 1 \\
\hline Ligustrum sinense & $\mathrm{S}$ & 1852 & & & & 1863 & & & & & & 0 \\
\hline Ligustrum vulgare & $\mathrm{S}$ & 1575 & $\mathrm{X}$ & $\mathrm{X}$ & $\mathrm{X}$ & 1857 & 1868 & & & $\mathrm{X}$ & $\mathrm{X}$ & 2 \\
\hline Lonicera fragrantissima & $\mathrm{S}$ & 1845 & & & & 1863 & & & & & & 1 \\
\hline Lonicera japonica & $\mathrm{S}$ & 1806 & & & & 1863 & 1880 & $\mathrm{X}$ & $\mathrm{X}$ & $X$ & $\mathrm{X}$ & 4 \\
\hline Lonicera maackii & $\mathrm{S}$ & 1855 & & & & & 1880 & & & $\mathrm{X}$ & $\mathrm{X}$ & 2 \\
\hline Lonicera morrowii & $\mathrm{S}$ & 1875 & & & & 1903 & & & $\mathrm{X}$ & $\mathrm{X}$ & $\mathrm{X}$ & 3 \\
\hline Lonicera standishii & $\mathrm{S}$ & 1845 & & & & 1903 & & & & $\mathrm{X}$ & & 1 \\
\hline Lonicera tatarica & $\mathrm{S}$ & 1752 & & & & 1863 & 1868 & $\mathrm{X}$ & $\mathrm{X}$ & $\mathrm{X}$ & & 3 \\
\hline Lonicera $x$ bella & $\mathrm{S}$ & 1878 & & & & & & & $\mathrm{X}$ & $X$ & & 2 \\
\hline Lonicera xylosteum & $\mathrm{S}$ & 1575 & $\mathrm{X}$ & & & 1873 & 1868 & $\mathrm{X}$ & $\mathrm{X}$ & & & 2 \\
\hline Maclura pomifera & $\mathrm{T}$ & 1818 & & & & 1857 & 1868 & & & & & 0 \\
\hline Melia azedarach & $\mathrm{T}$ & 1600 & $\mathrm{X}$ & $\mathrm{X}$ & $\mathrm{X}$ & & & & & & & 0 \\
\hline Morus alba & $\mathrm{T}$ & 1575 & $\mathrm{X}$ & $\mathrm{X}$ & $\mathrm{X}$ & 1857 & 1868 & & $\mathrm{X}$ & $\mathrm{X}$ & $\mathrm{X}$ & 3 \\
\hline Paulownia tomentosa & $\mathrm{T}$ & 1834 & & & & 1863 & 1868 & & & $\mathrm{X}$ & $\mathrm{X}$ & 2 \\
\hline Phellodendron amurense & $\mathrm{T}$ & 1856 & & & & 1903 & 1880 & $\mathrm{X}$ & $\mathrm{X}$ & $\mathrm{X}$ & & 3 \\
\hline Phellodendron japonica & $\mathrm{T}$ & 1863 & & & & & & & & & & 0 \\
\hline Picea abies & $\mathrm{T}$ & 1575 & & $\mathrm{X}$ & & 1863 & 1868 & & & & & 0 \\
\hline
\end{tabular}


Table 3. Cont.

\begin{tabular}{|c|c|c|c|c|c|c|c|c|c|c|c|c|}
\hline Taxa & $\begin{array}{c}\text { Growth } \\
\text { Form }\end{array}$ & $\begin{array}{c}\text { Year } \\
\text { Introduced }\end{array}$ & $\begin{array}{c}\text { North } \\
\text { America } \\
1818 \\
\end{array}$ & $\begin{array}{l}\text { Elgin } \\
1811 \\
\end{array}$ & $\begin{array}{c}\text { Harvard } \\
1818 \\
\end{array}$ & $\begin{array}{c}\text { Central } \\
1857-1903 \\
\end{array}$ & $\begin{array}{l}\text { Fairmount } \\
1868-1880 \\
\end{array}$ & MA & $\mathbf{N Y}$ & PA & DC & $\begin{array}{l}\text { Total } \\
\text { Occur }\end{array}$ \\
\hline Pinus sylvestris & $\mathrm{T}$ & 1575 & & & $\mathrm{X}$ & 1863 & 1868 & $\mathrm{X}$ & $\mathrm{X}$ & $\mathrm{X}$ & & 3 \\
\hline Pinus thunbergii & $\mathrm{T}$ & 1855 & & & & & 1880 & & & & & 0 \\
\hline Populus alba & $\mathrm{T}$ & 1575 & & $\mathrm{X}$ & & 1863 & 1868 & $\mathrm{X}$ & & $\mathrm{X}$ & $\mathrm{X}$ & 3 \\
\hline Prunus avium & $\mathrm{T}$ & 1625 & $X$ & $\mathrm{X}$ & & 1903 & 1868 & $\mathrm{X}$ & $\mathrm{X}$ & $\mathrm{X}$ & & 3 \\
\hline Prunus cerasus & $\mathrm{S}$ & 1575 & $\mathrm{X}$ & $\mathrm{X}$ & & 1903 & 1868 & & $\mathrm{X}$ & & & 1 \\
\hline Prunus mahaleb & $\mathrm{T}$ & 1575 & & & & 1863 & & & & $X$ & & 1 \\
\hline Prunus padus & $\mathrm{T}$ & 1575 & & $X$ & & 1863 & & & & $\mathrm{X}$ & & 1 \\
\hline Prunus persica & $\mathrm{T}$ & 1575 & & & & 1863 & 1868 & & & & & 0 \\
\hline Pueraria lobata & $\mathrm{S}$ & 1855 & & & & & & & & $\mathrm{X}$ & $\mathrm{X}$ & 2 \\
\hline Pyrus calleryana & $\mathrm{T}$ & 1908 & & & & & & & & $X$ & & 1 \\
\hline Pyrus malus & $\mathrm{T}$ & 1575 & $X$ & $X$ & & 1863 & 1868 & & & $\mathrm{X}$ & & 1 \\
\hline Quercus acutissima & $\mathrm{T}$ & 1862 & & & & & & & & & & 0 \\
\hline Rhamnus cathartica & $\mathrm{S}$ & 1575 & $\mathrm{X}$ & & & 1863 & 1880 & & $\mathrm{X}$ & $\mathrm{X}$ & & 2 \\
\hline Rhamnus frangula & $\mathrm{S}$ & 1575 & & & & 1863 & & $\mathrm{X}$ & $X$ & $\mathrm{X}$ & & 3 \\
\hline Rhodotypos scandens & $\mathrm{S}$ & 1866 & & & & 1903 & 1880 & $\mathrm{X}$ & $\mathrm{X}$ & & & 2 \\
\hline Ribes rubrum & $\mathrm{S}$ & 1575 & $X$ & $\mathrm{X}$ & $X$ & 1863 & 1868 & & & & & 0 \\
\hline Robinia hispida & $\mathrm{S}$ & 1758 & $\mathrm{X}$ & $\mathrm{X}$ & $\mathrm{X}$ & 1863 & 1868 & & & $\mathrm{X}$ & & 1 \\
\hline Robinia pseudoacacia & $\mathrm{T}$ & 1635 & $\mathrm{X}$ & $X$ & $X$ & 1857 & 1868 & & $\mathrm{X}$ & $\mathrm{X}$ & & 2 \\
\hline Rosa bracteata & $\mathrm{S}$ & 1793 & & & & & & & & & & 0 \\
\hline Rosa canina & $\mathrm{S}$ & 1575 & $\mathrm{X}$ & & & 1873 & 1880 & & & & & 0 \\
\hline Rosa carolina & $\mathrm{S}$ & 1826 & $\mathrm{X}$ & $\mathrm{X}$ & $X$ & 1857 & 1868 & $\mathrm{X}$ & $\mathrm{X}$ & $\mathrm{X}$ & & 3 \\
\hline Rosa gallica & $\mathrm{S}$ & 1575 & $\mathrm{X}$ & $\mathrm{X}$ & $\mathrm{X}$ & 1873 & & & & & & 0 \\
\hline Rosa micrantha & $\mathrm{S}$ & 1575 & & & & 1863 & & & $\mathrm{X}$ & & & 1 \\
\hline Rosa multiflora & $\mathrm{S}$ & 1868 & & $\mathrm{X}$ & & 1863 & 1880 & $\mathrm{X}$ & $\mathrm{X}$ & $\mathrm{X}$ & $\mathrm{X}$ & 4 \\
\hline Rosa rugosa & $\mathrm{S}$ & 1845 & & & & 1903 & & $X$ & $X$ & & & 2 \\
\hline Rosa wichuraiana & $\mathrm{S}$ & 1891 & & & & 1903 & & & & & & 0 \\
\hline Rubus armeniacus & $\mathrm{S}$ & 1770 & & & & & & & & & & 0 \\
\hline Rubus bifrons & $\mathrm{S}$ & 1818 & & & & & & & & & & 0 \\
\hline
\end{tabular}


Table 3. Cont.

\begin{tabular}{|c|c|c|c|c|c|c|c|c|c|c|c|c|}
\hline Taxa & $\begin{array}{c}\text { Growth } \\
\text { Form }\end{array}$ & $\begin{array}{c}\text { Year } \\
\text { Introduced }\end{array}$ & $\begin{array}{c}\text { North } \\
\text { America } \\
1818 \\
\end{array}$ & $\begin{array}{l}\text { Elgin } \\
1811 \\
\end{array}$ & $\begin{array}{c}\text { Harvard } \\
1818 \\
\end{array}$ & $\begin{array}{c}\text { Central } \\
1857-1903\end{array}$ & $\begin{array}{l}\text { Fairmount } \\
1868-1880\end{array}$ & MA & NY & PA & DC & $\begin{array}{l}\text { Total } \\
\text { Occur }\end{array}$ \\
\hline Rubus illecebrosus & $\mathrm{S}$ & 1895 & & & & & & & & & & 0 \\
\hline Rubus laciniatus & $\mathrm{S}$ & 1770 & & & & 1903 & 1880 & & & $\mathrm{X}$ & & 1 \\
\hline Rubus phoenicolasius & $\mathrm{S}$ & 1876 & & & & & & $\mathrm{X}$ & $X$ & $\mathrm{X}$ & $X$ & 4 \\
\hline Salix alba & $\mathrm{T}$ & 1575 & $\mathrm{X}$ & $\mathrm{X}$ & & 1863 & 1868 & & $\mathrm{X}$ & & & 1 \\
\hline Salix caprea & $\mathrm{T}$ & 1575 & & & & 1873 & 1868 & & & $\mathrm{X}$ & & 1 \\
\hline Salix cinerea & $\mathrm{S}$ & 1575 & & & & 1863 & & & & $\mathrm{X}$ & & 1 \\
\hline Salix fragilis & $\mathrm{T}$ & 1575 & & & & 1857 & 1868 & $\mathrm{X}$ & $\mathrm{X}$ & $\mathrm{X}$ & & 3 \\
\hline Salix pentandra & $\mathrm{S}$ & 1575 & & & $\mathrm{X}$ & 1863 & 1868 & $X$ & & $\mathrm{X}$ & & 2 \\
\hline Salix purpurea & $\mathrm{S}$ & 1575 & & & & 1863 & & $\mathrm{X}$ & & $\mathrm{X}$ & & 2 \\
\hline Salix $x$ sepulcralis & $\mathrm{T}$ & 1864 & & & & 1863 & & & $X$ & & $\mathrm{X}$ & 2 \\
\hline Sapium sebiferum & $\mathrm{T}$ & 1850 & & & & & 1880 & & & & & 0 \\
\hline Taxus cuspidata & $\mathrm{S}$ & 1855 & & & & 1873 & 1880 & & & & & 0 \\
\hline Ulmus parvifolia & $\mathrm{T}$ & 1794 & & & & 1873 & & & & & $X$ & 1 \\
\hline Ulmus pumila & $\mathrm{T}$ & 1860 & & & & 1863 & & $X$ & & $\mathrm{X}$ & & 2 \\
\hline Viburnum dilatatum & $\mathrm{S}$ & 1845 & & & & & & & & & $\mathrm{X}$ & 1 \\
\hline Viburnum opulus & $\mathrm{S}$ & 1575 & $\mathrm{X}$ & $\mathrm{X}$ & $\mathrm{X}$ & 1863 & 1868 & & & $X$ & & 1 \\
\hline Viburnum plicatum & $\mathrm{S}$ & 1865 & & & & 1903 & 1880 & & & & $X$ & 1 \\
\hline Viburnum sieboldii & $\mathrm{S}$ & 1880 & & & & 1903 & & & $X$ & $\mathrm{X}$ & & 2 \\
\hline Wisteria floribunda & $\mathrm{S}$ & 1830 & & & & & & & & & $X$ & 1 \\
\hline Wisteria sinensis & $\mathrm{S}$ & 1816 & & & & 1863 & 1880 & $\mathrm{X}$ & $\mathrm{X}$ & $\mathrm{X}$ & $\mathrm{X}$ & 3 \\
\hline Total & 98 & & 21 & 25 & 15 & 74 & 57 & 27 & 32 & 55 & 40 & 154 \\
\hline
\end{tabular}




\subsection{State Recognition of Invasive Species and Presence in Floras}

The invasive woody species from the Mid-Atlantic Exotic Pest Plant Council Plant List [38] recognized in the three states and the District of Columbia as a percentage of the 98 taxa for the region are: Massachusetts-28\%; New York-33\%, Pennsylvania-56\%; and District of Columbia-41\%. Regionally listed invasive woody taxa presence in the four most recent floras and not recognition at the state or District of Columbia level as a percentage of the invasive tree and shrub taxa in the 4 most recent flora are: Massachusetts-58\%; New York-52\%; Pennsylvania-26\%; and District of Columbia-35\%. The eight species listed in all three states and the District of Columbia and the species' presence in the 16 floras are: Acer platanoides-10; Ailanthus altissima-9; Berberis thunbergii-8; Celastrus orbiculatus-6; Lonicera japonica-10; Rosa multiflora-5; Rubus phoenicolasius-6; and Wisteria sinensis-5. None of the eight commonly recognized species were introduced to arboriculture before 1750 and the most recent year of introduction was 1876 which is particularly notable considering that more than half of the 36 taxa in 5 or more floras were introduced to arboriculture before 1750. Also, all eight species are present in all of the most recent floras for the remnant urban forests, which is again important to note since only 18 of the 98 taxa are present in the 4 most recent floras. Examining state lists for consensus on invasive woody species appears to be an effective means to identify recently introduced invasive woody taxa that are broadly distributed across the region. The Pearson product moment correlation between the number of the 16 floras containing an invasive woody taxon and the number of state or District of Columbia recognitions of the woody taxon as invasive is significant at the 0.05 level. Also, the Pearson product moment correlation between the number of the 4 most recent floras of the remnant urban forests containing an invasive woody taxon and the number of state or District of Columbia recognitions of the woody taxon as an invasive is significant at the 0.05 level.

The significant results of the Pearson product moment analysis indicate good recognition of regionally designated invasive woody taxa at the state and District of Columbia level considering both presence in recent floras and presence in floras over the long-term. However, no state or District of Columbia recognition of regionally invasive woody taxa present in the recent floras ranges from $26 \%$ to $58 \%$ of the invasive trees and shrubs in the remnant urban forests in this research. Also, with only $18 \%$ of woody taxa in the Mid-Atlantic Exotic Pest Plant Council Plant List [38] occurring in all 4 most recent floras, all of the listed invasive shrubs and trees are not pervasive across the remnant urban forests. Considering the recognition of and distribution of invasive woody taxa, floristic monitoring of remnant urban forests is essential to determine if particular invasive woody species have an expanding range [43]. Recent phenomena such as warming climate causing growing conditions to become more favorable for invasive woody taxa [44] and the introduction of large herbivores which open habitats [45] can permit invasive trees and shrubs to rapidly spread across a remnant urban forest. Knowing which invasive trees and shrubs are present is the first step in achieving the goal of invasive woody species eradication [46]; however, arguments are being made to eschew the negative connotations of alien and invasive species and to not support eradication efforts [47]. In light of the varying distribution of regionally recognized invasive woody species as revealed by the floristic data examined in this study, the approach to follow is to evaluate whether the presence of an invasive shrub 
or tree creates a problem that is changing forest ecology and only then if necessary to remediate the problem by performing treatments to restore ecological conditions [48].

\section{Conclusions}

Over the time period 1818-2011, the number of invasive woody taxa significantly increased in the four urban remnant forests in four cities across the coastal oak-chestnut forest region. Pearson product moment correlation analysis revealed no significant correlations for residence time (date of introduction into arboriculture) and presence in the: (1) 16 floras; (2) 4 cities; and (3) most recent flora for the four remnant forests. However, the flora analysis did indicate that searching in the earliest urban floras for invasive woody taxa can reveal common invasive trees and shrubs in modern remnant urban forests. In contrast to residence time, planting intensity based on both the 1811-1818 and 1857-1903 floras did have significant correlations with the 16 floras, as well as only the most recent floras for the remnant urban forests. The earlier floras (1811-1818) used for the planting intensity analysis are also reliable indicators of invasive woody taxa presence in the most recent floras of the urban remnant forests. The District of Columbia and state recognition of regionally listed invasive woody taxa showed significant correlations with presence in all 16 floras as well as the most recent floras for the remnant urban forests. However, recognition by the District of Columbia and the 3 states did not account for $26 \%$ to $58 \%$ of the invasive trees and shrubs in the four remnant urban forests. Monitoring for range expansion by the regional invasive woody taxa is essential for state level recognition as well as specific remnant urban forest management because only $18 \%$ of the 98 taxa are present in all 4 of the most recent remnant urban forest floras.

\section{Acknowledgments}

The 2004 listing of species for Wissahickon Creek was provided by Richard Horwitz, Ann Rhoads, and Ernie Schuyler, with funding from the Natural Lands Restoration and Environmental Education Program of the Fairmont Park Commission under a grant from the William Penn Foundation. Thanks are extended to Diane Pavek for sharing the Rock Creek Park Vascular Plant Certified Species List 4 December 2011 and to Bryan Hamlin for sharing the Middlesex Fells Reservation flora of 2011. Through the courtesy of Steve Ward, the photograph of Radnor Lake State Natural Area showing adjacent sites with Lonicera maackii removal and not treated was included in the graphic abstract.

\section{Conflict of Interest}

The author declares no conflict of interest.

\section{References}

1. Reichard, S.H.; White, P. Horticulture as a pathway of invasive plant introductions in the United States. Bioscience 2001 51, 103-113.

2. McKinney, M.L. Influence of settlement time, human population, park shape and age, visitation and roads on the number of alien plant species in protected areas in the USA. Divers. Distrib. 2002, 8, 311-318. 
3. Leighton, A. American Gardens of the Nineteenth Century; University Massachusetts Press: Amherst, MA, USA, 1987.

4. Adams, D.W. Restoring American Gardens; Timber Press: Portland, OR, USA, 2004.

5. Loeb, R.E. Will a tree grow in Brooklyn? Developmental trends of the New York City street tree forest. J. For. 1992, 90, 20-24.

6. Loeb, R.E. Diversity gained, diversity lost: Long-term changes in the woody species planted in Central Park, New York City and Fairmount Park, Philadelphia. Stud. Hist. Gard. Des. Landsc. 2010, 30, 124-151.

7. Loeb, R.E. Old Growth Urban Forests; Springer: New York, NY, USA, 2011.

8. Theoharides, K.A.; Dukes, J.S. Plant invasion across space and time: factors affecting nonindigenous species success during the four stages of invasion. New Phytol. 2007, 176, 256-273.

9. Magurran, A.E.; Baillie, S.R.; Buckland, S.T.; Dick, J.M.; Elston, D.A.; Scott, E.M.; Smith, R.I.; Somerfield, P.J.; Watt, A.D. Long-term datasets in biodiversity research and monitoring: Assessing change in ecological communities through time. Trends Ecol. Evol. 2010, 25, 574-582.

10. Kent, M.; Stevens, R.A.; Zhang, L. Urban plant ecology patterns and processes: A case study of the flora of the City of Plymouth, Devon, U. K. J. Biogeogr. 1999, 26, 1281-1298.

11. Chocholušková, Z.; Pyšek, P. Changes in the composition and structure of urban flora over 120 years: A case study in the city of Plzeň. Flora 2003, 198, 366-376.

12. DeCandido, R.; Muir, A.A.; Gargiullo, M.B. A first approximation of the historical and extant vascular flora of New York City: Implications for native plant species conservation. J. Torr. Bot. Club 2004, 131, 243-251.

13. Van der Veken, S.; Verheyen, K.; Hermy, M. Plant species losses in an urban area (Turnhout, Belgium) from 1880 to 1999 and its environmental determinants. Flora 2004, 199, 516-523.

14. Tait, C.J.; Daniels, C.B.; Hill, R.S. Changes in species assemblages within the Adelaide metropolitan area, Australia, 1836-2002. Ecol. Appl. 2005, 15, 346-359.

15. Lososová, Z.; Simonová, D. Changes during the 20th century in species composition of synanthropic vegetation in Moravia (Czech Republic). Preslia 2008, 80, 291-305.

16. Mulvaney, M. The Effect of Introduction Pressure on the Naturalization of Ornamental Woody Plants in South-Eastern Australia. In Weed Risk Assessment; Groves, R.H., Panetta, F.D., Virtue, J.G., Eds.; CSIRO Publishing: Collingwood, Australia, 2001; pp. 186-193.

17. Dehnen-Schmutz, K.; Touza, J.; Perrings, C.; Williamson, M. The horticultural trade and ornamental invasions in Britain. Conserv. Biol. 2007, 21, 224-231.

18. Bucharova, A.; van Kleunen, M. Introduction history and species characteristics partly explain success of North American woody species in Europe. J. Ecol. 2009, 97, 230-238.

19. Pyšek, P.; Křivánek, M.; Jarošík, V. Planting intensity, residence time, and species traits determine invasion success of alien woody species. Ecology 2009, 90, 2734-2744.

20. Profous, G.V.; Loeb, R.E. New York City forests and the natural area districts. Arbor. J. 1986, 10, 131-150.

21. Braun, E.L. Deciduous Forests of Eastern North America; Hafner Publishing: New York, NY, USA, 1950. 
22. Bigelow, J. Florula Bostoniensis: A Collection of Plants of Boston and Its Environs, With Their Generic and Specific Characters, Synonyms, Descriptions, Places of Growth, and Time of Flowering, and Occasional Remarks; Charles, C., Ed.; Little and James Brown: Boston, MA, USA, 1840.

23. Torrey, J. Catalogue of Plants Growing Spontaneously Within Thirty Miles of the City of New York; Websters and Skinners: Albany, NY, USA, 1819.

24. Barton, W.P.C. Compendium Florae Philadelphicae: Containing a Description of the Indigenous and Naturalized Plants Found Within a Circuit of Ten Miles Around Philadelphia; M. Carey and Son: Philadelphia, PA, USA, 1818; Volumes 1 and 2.

25. Brereton, J.A. A Prodromus of the Flora Columbiana, Exhibiting a List of All the Plants Which Have as Yet Been Collected; Jonathon Elliot: Washington, DC, USA, 1830.

26. Deane, W. Flora of the Blue Hills, Middlesex Fells, Stony Brook and Beaver Brook Reservations of the Metropolitan Park Commission, Massachusetts; C.M. Barrows \& Co.: Boston, MA, USA, 1896.

27. Willis, O.R. Report of the Flora of Westchester County; Roper \& Burdge: New York, NY, USA, 1880.

28. Keller, I.A.; Brown, S. Handbook of the Flora of Philadelphia and Vicinity; Philadelphia Botanical Club: Philadelphia, PA, USA, 1905.

29. Hitchcock, A.S.; Stanley, P.C. Flora of the District of Columbia and Vicinity; Contributions from the United States National Herbarium, Government Printing Office: Washington, DC., USA, 1919; Volume 21;

30. Drayton, B.E. Changes in the Flora of the Middlesex Fells 1894-1993; M.A. thesis, Boston University: Boston, MA, USA, 1993.

31. DeCandido, R.V. Recent Changes in Plant Species Diversity in Pelham Bay Park, Bronx County, New York City, 1947-1998; Ph.D. thesis; City University of New York: New York, NY, USA, 2001.

32. Fogg, J.M. Annotated checklist of the plants of the Wissahickon Valley. Bartonia 1996, 59, 1-36.

33. Fleming, P.; Kanal, R. Annotated checklist of vascular plants of Rock Creek Park, National Park Service, Washington, D.C. Castanea 1995, 60, 283-316.

34. Hamlin, B.T.; Kittredge, W.T.; Lubin, D.P.; Wright, E.B. Changes in the vascular flora of the Middlesex Fells Reservation, Middlesex County, Massachusetts, from 1895 to 2011. Rhodora 2012, 114, accepted.

35. Horwitz, R.J.; Rhoads, A.; Schuyler, A.E. Species List. Natural Lands Restoration and Environmental Education Program, Fairmont Park Commission: Philadelphia, PA, USA. Unpublished work, 2004.

36. Pavek, D.S. Rock Creek Park Vascular Plant Certified Species List December 4, 2011. Unpublished work, 2011.

37. Bailey, L.H.; Bailey, E.Z. Staff of Liberty Hyde Bailey Hortorium. Hortus Third; Macmillan Publishing Co.: New York, NY, USA, 1976.

38. United States National Parks Service Alien Plant Working Group. Mid-Atlantic List of Invasive Plants. Available online: http://www.nps.gov/plants/alien/list/midatlantic.htm (accessed on 29 May 2012). 
39. Rehder, A. Manual of Cultivated Trees and Shrubs Hardy in North America, Exclusive of the Subtropical and Warmer Temperate Regions; Macmillan Company: New York, NY, USA, 1940.

40. Hosack, D. Hortus Elginensis or a Catalogue of Plants Indigenous and Exotic Cultivated in the Elgin Botanic Garden, in the Vicinity of the City of New-York; T.O.J. Swords: New York, NY, USA, 1811.

41. Muhlenberg, H. A Catalogue of the Hitherto Known Native and Naturalized Plants of North America, Arranged According to the Sexual System of Linnaeus; Solomon, W., Ed.; Conrad: Philadelphia, PA, USA, 1818.

42. Peck, W.D. A Catalogue of American and Foreign Plants, Cultivated in the Botanic Garden, Cambridge, Massachusetts; Hillard and Metcalf at the University Press: Cambridge, MA, USA, 1818.

43. Holcombe, T.; Stohlgren, T.J. Detection and Early Warning of Invasive Species. In Invasive Species Management a Handbook of Principles and Techniques; Clout, M.C., Williams, P.A., Eds.; Oxford University Press: Oxford, UK, 2009; pp. 36-46.

44. Bradley, A.B.; Blumenthal, D.M.; Early, R.; Grosholz, E.D.; Lawler, J.J.; Miller, L.P.; Sorte, C.J.B.; D’Antonio, C.M.; Diez, J.M.; Dukes, J.S.; et al. Global Change, global trade, and the next wave of plant invasions. Front. Ecol. Environ. 2012, 10, 20-28.

45. Aronson, M.F.J.; Handel, S.N. Deer and invasive plant species suppress forest herbaceous communities and canopy tree regeneration. Nat. Areas J. 2011, 31, 400-407.

46. Parkes, J.P.; Panetta, F.D. Eradication of Invasive Species: Progress and Emerging Issues in the 21st Century. In Invasive Species Management a Handbook of Principles and Techniques; Clout, M.C., Williams, P.A., Eds.; Oxford University Press: Oxford, UK, 2009; pp. 47-60.

47. McNeeley, J.A. Xenophobia or Conservation: Some Human Dimensions of Invasive Alien Species. In Invasive and Introduced Plants and Animals: Human Perceptions, Attitudes, and Approaches to Management; Rotherham, I.D., Lambert, R.A., Eds.; Earthscan: London, UK, 2011; pp. 19-38.

48. Rotherham, I.D.; Lambert, R.A. Good Science, Good History, and Pragmatism: Managing the Way Ahead. In Invasive and Introduced Plants and Animals: Human Perceptions, Attitudes, and Approaches to Management; Rotherham, I.D., Lambert, R.A., Eds.; Earthscan: London, UK, 2011; pp. 355-366.

(C) 2012 by the author; licensee MDPI, Basel, Switzerland. This article is an open access article distributed under the terms and conditions of the Creative Commons Attribution license (http://creativecommons.org/licenses/by/3.0/). 